\title{
GEOLOGICAL SURVEY OF FINLAND RADIOCARBON MEASUREMENTS III
}

\author{
E. HYYPPÄ, A. V. P. TOIVONEN and A. ISOLA
}

$\mathrm{C}^{14}$-Laboratory, Geological Survey of Finland, Otaniemi, Finland

The following results represent measurements carried out since our second date list was prepared. The pretreatment of the samples and the production of pure $\mathrm{CO}_{2}$ followed the method described in Finland I.

\section{SAMPLE DESCRIPTIONS}

GEOLOGIC SAMPLES

\section{Su-26. Pello, Finnish Lapland}

$3830 \pm 130$

1880 в.C.

Carex-Sphagnum peat from hand-dug section, depth 2.0 to $2.1 \mathrm{~m}$, surface alt $84 \mathrm{~m}$, Tornio River Valley ( $66^{\circ} 46^{\prime} \mathrm{N}$ Lat, 24 $04^{\prime} \mathrm{E}$ Long). Coll. 1955 by Esa Hyyppä. Comment: dating made from the basal part of the same section as Su-25 (Hyyppä and others, 1962).

\section{Su-27. Pori, W Finland, Kiikoinen}

$1350 \pm 140$

$$
\text { A.D. } 600
$$

Wood from a trough, found in peat bog, depth 0.60 to $0.65 \mathrm{~m}$, surface alt $80.7 \mathrm{~m}$, Kiikoinen, Jylhämaa (61 $30^{\prime} \mathrm{N}$ Lat, $22^{\circ} 31^{\prime} \mathrm{E}$ Long). Coll. 1961 Mus. of Satakunta, Pori. Comment: according to pollen analysis, horizon represents approx. the middle of Sub-Atlantic period.

\section{Su-28. Metsäpirtti, Karelian Isthmus USSR $\quad 7110 \pm 170$}

Wood from upper part of peat section under silt and fine sand, bank of

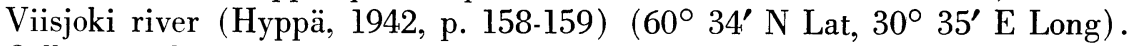
Coll. 1937 by Esa Hyyppä. Comment: according to pollen analysis, horizon roughly corresponds to beginning of Littorina (L I) ; the Ladoga transgression seems to have begun at this time, and its water was in the initial stage only 1 to $2 \mathrm{~m}$ above the sealevel of Littorina I.

\section{Su-29. Saarijärvi, Middle Finland}

$4400 \pm 130$

\section{B.c.}

Deciduous-Polypodiaceae peat, depth $0.3 \mathrm{~m}$, alt $127.2 \mathrm{~m}$, Mahlu Herrainkorpi peat bog $\left(62^{\circ} 40^{\prime} \mathrm{N}\right.$ Lat, $2^{\circ} 20^{\prime} \mathrm{E}$ Long $)$. Coll. 1962 by Martti Salmi. Comment: according to pollen analysis, horizon represents beginning of spread of spruce (Salmi, 1963a).

\section{Su-30. Saarijärvi, Middle Finland}

$8490 \pm 200$

\section{0 в.c.}

The same peat bog as Su-29, Phragmites-Equisetum peat, depth $1.3 \mathrm{~m}$, alt $126.2 \mathrm{~m}$. Coll. 1962 by M. Salmi. Comment: according to pollen analysis, horizon represents Boreal Pinus maximum (Salmi 1963a, b) .

\section{Su-31. Pello, Finnish Lapland}

$6170 \pm 160$

4220 в.c.

Coarse detritus, depth 3.9 to $4.0 \mathrm{~m}$, surface alt $91.6 \mathrm{~m}$, Pello $\left(66^{\circ} 46^{\prime} \mathrm{N}\right.$ Lat, $24^{\circ} 04^{\prime} \mathrm{E}$ Long). Coll. 1962 by E. Hyyppä. Comment: according to pollen 
analysis, horizon belongs to first half of Littorina stage, when the sea shore had already retreated below the local Littorina maximum (LI). Local LI 94 m above sealevel (Hyyppä, 1963).

\section{Su-32. Ylöjärvi, W Finland}

$7080 \pm 140$

5130 в.C.

Peat on top of clayey ooze, depth $0.6 \mathrm{~m}$, surface alt $100 \mathrm{~m}\left(61^{\circ} 42^{\prime} \mathrm{N}\right.$ Lat, $23^{\circ} 35^{\prime}$ E Long). Coll. 1962 by E. Kae. Comment: according to pollen analysis, the peat represents beginning of Littorina period and the underlying ooze represents transgression of Lake Näsijärvi, due to land uplift.

\section{Su-33. Isokyrö, W Finland \\ A.D. 1450 \\ $500 \pm 100$}

Betula wood from the foundation pile of a stone church, Isokyrö $\left(63^{\circ} 60^{\prime}\right.$ $\mathrm{N}$ Lat, $22^{\circ} 20^{\prime} \mathrm{E}$ Long). Comment: $\mathrm{C}^{14}$ date agrees with historical documents.

\section{REFERENCES}

Date lists:

Finland I Hyyppä, Hoffren, Isola, 1962

Finland II Hyyppä, Isola, Hoffren, 1963

Hyyppä, Esa, 1942, Beiträge zur Kenntnis der Ladoga- und Ancylustransgression: C. R. Soc. Géol. Finlande, no. 15, p. 137-177. p. $37-48$.

Hyyppä, E., Hoffren, V., Isola, A., 1962, Geological survey of Finland radiocarbon measurements I: Radiocarbon, v. 4, p. 81-83.

Hyyppä, E., Isola, A., Hoffren, V., 1963, Geological survey of Finland radiocarbon measurements II: Radiocarbon, v. 5, p. 302-304.

Salmi, Martti, 1963a, On the Late-Quaternary distribution in Finland of the filbert (Corylus avellana L.) : Bull. Comm. Géol. Finlande, no. 207, p. 1-67.

1963b, On the Subfossil Pediastrum Algae and Molluses in the Late-Quaternary Sediments of Finnish Lapland: Arch. Soc. Zool. Bot. Fennicae "Vanamo" 18:2, p. 105-120. 